\title{
Correction to: Delivery of oncolytic vaccinia virus by matched allogeneic stem cells overcomes critical innate and adaptive immune barriers
}

Dobrin D. Draganov ${ }^{1 *}$, Antonio F. Santidrian', Ivelina Minev', Duong Nguyen ${ }^{1}$, Mehmet Okyay Kilinc ${ }^{1}$, Ivan Petrov ${ }^{2}$, Anna Vyalkova ${ }^{2}$, Elliot Lander ${ }^{4}$, Mark Berman $^{4}$, Boris Minev ${ }^{1,3}$ and Aladar A. Szalay ${ }^{1,2,3^{*}}$

\section{Correction to: J Transl Med (2019) 17:100}

https://doi.org/10.1186/s12967-019-1829-z

The authors declare that a patent application entitled "Cell-based vehicles for potentiation of viral therapy" has been filed on August 8, 2019 by the inventors Dobrin Draganov and Aladar A. Szalay [1].

\section{Author details}

${ }^{1}$ Calidi Biotherapeutics, San Diego, CA 92121, USA. ${ }^{2}$ Institute of Biochemistry, Biocentre, University of Wuerzburg, Am Hubland, 97070 Würzburg, Germany. ${ }^{3}$ Radiation Oncology, Moores Cancer Center, University of California San Diego, La Jolla, San Diego, CA 92037, USA. ${ }^{4}$ California Stem Cell Treatment Center, Rancho Mirage, CA 92270, USA.

Published online: 04 October 2021

\begin{abstract}
Reference
1. Draganov DD, Santidrian A, Minev l, et al. Delivery of oncolytic vaccinia virus by matched allogeneic stem cells overcomes critical innate and adaptive immune barriers. J Transl Med. 2019;17:100. https://doi.org/10. 1186/s12967-019-1829-z.
\end{abstract}

\section{Publisher's Note}

Springer Nature remains neutral with regard to jurisdictional claims in published maps and institutional affiliations.

The original article can be found online at https://doi.org/10.1186/s12967019-1829-z.

*Correspondence: ddraganov@calidibio.com; szalay@biozentrum.uniwuerzburg.de; aszalay@aol.com

${ }^{1}$ Calidi Biotherapeutics, San Diego, CA 92121, USA

${ }^{2}$ Institute of Biochemistry, Biocentre, University of Wuerzburg, Am Hubland, 97070 Würzburg, Germany

Full list of author information is available at the end of the article permits use, sharing, adaptation, distribution and reproduction in any medium or format, as long as you give appropriate credit to the original author(s) and the source, provide a link to the Creative Commons licence, and indicate if changes were made. The images or other third party material in this article are included in the article's Creative Commons licence, unless indicated otherwise in a credit line to the material. If material is not included in the article's Creative Commons licence and your intended use is not permitted by statutory regulation or exceeds the permitted use, you will need to obtain permission directly from the copyright holder. To view a copy of this licence, visit http://creativecommons.org/licenses/by/4.0/. The Creative Commons Public Domain Dedication waiver (http://creativeco mmons.org/publicdomain/zero/1.0/) applies to the data made available in this article, unless otherwise stated in a credit line to the data. 